\title{
Charakterystyka mikrolitofacji oraz warunków paleotemperaturowych skal ediakaru w otworze wiertniczym Bibiela PIG-1
}

\author{
Marta Kuberska ${ }^{1}$, Aleksandra Kozlowska ${ }^{1}$, Magdalena Sikorska-Jaworowska ${ }^{2}$, Izabella Grotek ${ }^{2}$
}

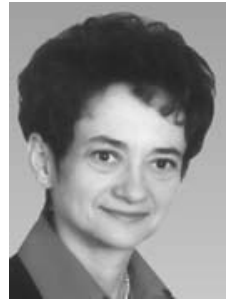

M. Kuberska

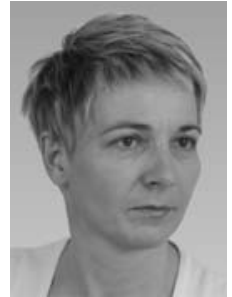

A. Kozłowska

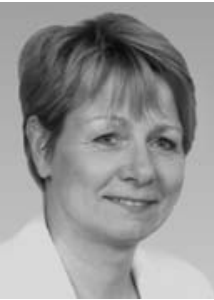

M. Sikorska-Jaworowska



I. Grotek

The characteristics of microlithofacies and palaeotemperature conditions of Ediacaran rocks in the Bibiela PIG-1 borehole. Prz. Geol., 69: 374-378; doi: 10.7306/2021.20

A b s tr a ct. The paper presents results of new petrographic and mineralogical analyses of Ediacaran clastic rocks in the Bibiela PIG-1 borehole drilled in 2016. Three types of microlithofacies have been distinguished. The basic types of rocks are siltstones and claystones containing thin layers of mudstones. Breccia is common, while sandstones form thin packages. The Ediacaran rocks are cut by numerous veins that intersect each other. They are filled with carbonates, quartz, chlorites and kaolinite. Ankerite, Fe-dolomite, dolomite, Mg-siderite (sideroplesite, pistomesite, metisite), Mn-siderite (manganosiderite) and Fe/Mn-calcite were identified among the carbonate minerals. Vitrinite reflectance index Ro (1.68\%), Kübler index KI (0.72 to $\left.1.10 \Delta^{\circ} 2 \theta C u K_{2}\right)$ and smectite content (10-25\%) in the mixed-layer illite/smectite indicate that the Ediacaran rocks in the Bibiela PIG-1 borehole have been altered under the conditions of late diagenesis at the maximum temperature estimated at approx. $160^{\circ} \mathrm{C}$.

Keywords: microlithofacies, palaeotemperature conditions, Ediacaran, Bibiela PIG-1 borehole

Otwór badawczy Bibiela PIG-1 odwiercono w 2016 r. w odległości $12 \mathrm{~km}$ na północy zachód od Siewierza. Celem wiercenia było rozpoznanie budowy geologicznej północno-wschodniej części bloku górnośląskiego. Wiercenie to przyczyniło się do zmiany nazwy struktury geologicznej (Markowiak, Habryn, 2020) - z antykliny Brudzowic na elewacyjną strukturę Brudzowic (Siewierza). W profilu otworu rozpoznano utwory ediakaru, ordowiku, dewonu dolnego oraz triasu (Habryn, 2017). Utwory ediakaru udokumentowano na podstawie pojedynczych okazów prostych, sferycznych form reprezentujących rodzaj Leiosphaeridia oraz nitkowatych sinic (Cyanobacteria) (Habryn, Bagińska, 2020). Skały klastyczne ediakaru występują na głębokości: 711,0-1650,0 m p.p.t., na nich niezgodnie (kontakt tektoniczny) zalegają utwory klastyczne ordowiku (Habryn, Bagińska, 2020). Celem badań była analiza petrograficzna utworów ediakaru, które po raz pierwszy stwierdzono w rejonie bloku górnośląskiego. Dobrze rozpoznane utwory ediakaru występują w basenie lubelsko-podlaskim, gdzie zidentyfikowano skały silikoklastyczne (zlepieńce, piaskowce, mułowce i iłowce) oraz wulkanogeniczne (Pacześna, 2014). Utwory ediakaru rozpoznano również w bloku małopolskim (Buła, Habryn, 2008).

\section{METODY BADAŃ}

Pod mikroskopem polaryzacyjnym Optiphot $2 \mathrm{Pol}$ firmy Nikon przeprowadzono badania petrograficzne 132 płytek cienkich, analizując skład mineralny skał ediakaru z profilu otworu Bibiela PIG-1 oraz ich cechy strukturalne i teksturalne. Oprócz standardowych badań mikroskopowych wszystkich płytek cienkich przeprowadzono też obserwacje w katodoluminescencji (CL) z wykorzystaniem aparatury CCL $8200 \mathrm{mk} 3$ firmy Cambridge Image Technology. Wyniki tych badań umożliwiły odczytanie pierwotnych cech teksturalnych oraz lepsze poznanie i zinterpretowanie procesów diagenetycznych, jakim były poddane skały. 16 próbek zbadano pod mikroskopem elektronowym $L E O 1430$, wyposażonym w detektor dyspersji energii (EDS) Oxford ISIS 300. Analizowano płytki cienkie napylone węglem - wykonano 35 analiz chemicznych minerałów węglanowych oraz 21 analiz innych minerałów, m.in. chlorytów, skaleni, barytu i apatytu.

Za pomoca dyfraktometru rentgenowskiego firmy Philips X'Pert PW 3020 z lampa $\mathrm{Cu}$ i detektorem półprzewodnikowym wykonano analizy rentgenowskie (XRD) 12 próbek skał ilastych. Aparat był wyposażony w komputerowy system identyfikacji proszkowej APD 1877.

\footnotetext{
${ }^{1}$ Państwowy Instytut Geologiczny - Państwowy Instytut Badawczy, ul. Rakowiecka 4, 00-975 Warszawa; marta.kuberska@pgi.gov.pl; aleksandra.kozlowska@pgi.gov.pl

2 emerytowany pracownik Państwowego Instytutu Geologicznego - Państwowego Instytutu Badawczego
} 
Skład fazowy próbek określono na podstawie położenia pików, które porównano ze wzorcami JCPDS. Analizowano zarówno skład mineralny sproszkowanych całych próbek, jak i wydzielonej $\mathrm{z}$ nich frakcji $<2 \mu \mathrm{m}$. Separację wykonano, stosując metodykę Moora i Reynoldsa jr. (1989). Badano preparaty orientowane w stanie powietrzno-suchym oraz po glikolowaniu i prażeniu do temperatury ok. $550^{\circ} \mathrm{C}$, rejestrując refleksy w zakresie katowym $0-30^{\circ} 2 \theta$. Zbadano także tzw. stopień krystaliczności illitu, określany jako indeks Küblera (KI).

Badaniom mikroskopowym materii organicznej poddano 13 polerowanych płytek skał osadowych zawierających materiał witrynitopodobny o cechach optycznych witrynitu. Pomiary wykonano w imersji, w świetle odbitym białym, pod mikroskopem badawczym Axio Imager firmy Zeiss z optyką ICS (Infinity Colour Corrected System), z wyposażeniem optycznym do światła odbitego, zestawem mikrofotometru (Spektrometr CCD SPECTRA $V I S I O N)$ z systemem fotometrycznym oraz specjalistycznym oprogramowaniem PMT 200 firmy $J \& M \mathrm{GmbH}$ do pomiarów zdolności refleksyjnej materii organicznej.

W badanym profilu otworu Bibiela PIG-1 wyróżniono litofacje: brekcjową, piaskowcową, mułowcową, pyłowcową i iłowcową (ryc. 1A-F - patrz str. 393; 2A-F). W klasyfikacji piaskowców posłużono się podziałem Pettijohna i in. (1972), a do opisu iłowców i pyłowców przyjęto podział Tuckera (2001).

W prowadzeniu analiz i interpretacji ich wyników poza autorkami artykułu uczestniczyli: Wanda Narkiewicz (badania XRD), Leszek Giro (badania SEM) oraz Iza Matejko (separacja frakcji ilastej). Badania wykonano w PIG-PIB w Warszawie.

\section{WYNIKI BADAŃ}

\section{Charakterystyka mikrolitofacji}

W górnej części profilu otworu Bibiela PIG-1, do głębokości ok. 1000 m p.p.t. występują głównie brekcje i piaskowce ediakaru, natomiast poniżej dominują mułowce, pyłowce i iłowce pochodzące $\mathrm{z}$ tego samego okresu. Zgeneralizowany profil tego otworu zamieszczono w pracy Markowiaka i Habryna (2020).

Litofacja brekcjowa (ryc. 1A-F) powszechnie występuje w górnej części profilu ediakaru, a w niższej stanowi liczne wkładki w iłowcach i pyłowcach. Jednak jej miąższe pakiety notowano jedynie w stropie ediakaru. Sa to skały barwy czerwonobrunatnej, przechodzące ku spagowi w beżowozielonkawe i zielonkawooliwkowe. Skład brekcji jest mało urozmaicony, przy czym nieco większe zróżnicowanie w składzie frakcji psefitowej obserwuje się w stropie profilu. Litoklasty są przeważnie nieobtoczone, rzadziej półobtoczone. Ich wielkość jest bardzo zróżnicowana: od kilku do kilkudziesięciu centymetrów, zazwyczaj ok. 3-4 cm. Jako składnik frakcji psefitowej występują w tej brekcji fragmenty piaskowców, głównie drobnoziarnistych o składzie waki sublitycznej. Okruchy tych piaskowców mają przeważnie barwę zielonkawą na skutek dużej zawartości chlorytów. Są to głównie chloryty powstałe jako efekt procesów przeobrażania diagenetycznego skaleni, fragmentów skał lub łyszczyków. Poza litoklastami piaskowców w brekcji zauważono fragment skały wulkanoklastycznej, skarbonatyzowanej. Okruchy brekcji są scementowane masą ila- sto-pylastą, miejscami zażelazioną (szczególnie w części przystropowej profilu ediakaru). Na podstawie analizy rentgenowskiej wśród minerałów ilastych zidentyfikowano: illit, minerały mieszanopakietowe illit/smektyt a także chloryty. Skomplikowany obraz strukturalno-teksturalny skały jest podkreślony licznymi, przecinającymi się żyłkami. Żyłki te są wypełnione węglanami (ryc. 3), kwarcem, chlorytami, a także kaolinitem. Powszechnie występuje ankeryt, Fe-dolomit i dolomit (ryc. 1C, D). Obserwowano także skupienia drobnych, wydłużonych romboedrów Mg-syderytu o składzie chemicznym syderoplesytu (ryc. 2B), pistomezytu, miejscami, w środkowej części, metisytu (ryc. 3). Oprócz tego, posługując się analizą rentgenowską, wykryto w jednej próbce obecność magnezytu. Wydaje się, że wraz z głębokością wzrasta udział Mg-syderytu o składzie chemicznym syderoplesytu, występującego w postaci smug, wypełnień spękań lub skupień. Odnotowano także obecność żyłek ankerytowo-kaolinitowych i kwarcowych. Sieć bardzo drobnych spękań bywa wypełniona chlorytami magnezowo-żelazistymi. Wyniki analizy katodoluminescencyjnej i dyfraktometrycznej potwierdziły także obecność kalcytu, często jako reliktu w żyłkach ankerytowych, lub wypełnienia spękań dwoma jego generacjami (ryc. 1E, F). W obrazie CL starsza generacja charakteryzuje się żółtą barwą luminescencji, a młodsza - barwą pomarańczową, co jest związane ze stosunkiem $\mathrm{Mn}^{2+}$ do $\mathrm{Fe}^{2+} \mathrm{w}$ składzie chemicznym kalcytu.

Litofacja piaskowcowa (ryc. 2A, B) tworzy w opisywanym profilu ediakaru niewielkiej miąższości pakiety lub cienkie przeławicenia w iłowcach lub pyłowcach. Piaskowce są barwy zielonkawobrunatnej, przechodzącej ku spagowi profilu w zielonkawooliwkową. Ciemne, brunatne zabarwienie jest związane $\mathrm{z}$ rozproszoną obecnością związków żelaza, skupień pirytu lub nagromadzeń materii organicznej. Piaskowce mają strukturę psamitową lub psamitowo-aleurytowa, teksturę bezładną, rzadziej kierunkową, podkreśloną cienkimi laminkami pyłowca lub mułowca. Składem odpowiadają wakom sublitycznym lub też subarkozowym. Głównym składnikiem materiału detrytycznego są ziarna kwarcu mono- i polikrystalicznego. Oprócz kwarcu zidentyfikowano skalenie potasowe i plagioklazy, które w dużym stopniu są przeobrażone (albityzacja, argilityzacja) lub częściowo rozpuszczone. Liczną grupę stanowią litoklasty. Należą do nich fragmenty szkliwa wulkanicznego (najprawdopodobniej schlorytyzowanego), skał krzemionkowych i iłowców. Ponadto występują: apatyt, biotyt (przeważnie schlorytyzowany), cyrkon, ilmenit, hematyt, leukoksen i miejscami piryt. Spoiwem piaskowców jest matriks składający się z chlorytów i illitu, co potwierdziły wyniki analizy rentgenowskiej. Obecne są również rozproszone tlenki i wodorotlenki żelaza oraz materia organiczna. Miejscami materia organiczna jest reprezentowana przez bituminy, które tworzą nagromadzenia w postaci przemazów i wypełnień w żyłkach (ryc. 2A). Bardzo często piaskowce są poprzecinane żyłkami wypełnionymi kwarcem lub węglanami (kalcyt, Fe-dolomit). Zauważono również strefy wzbogacone w chloryty, które tworzą większe skupienia (ryc. 2B). Są one barwy zielonkawej, o wyraźnym pleochroizmie i subnormalnych barwach interferencyjnych. W piaskowcach zaobserwowano bardzo liczne efekty działania procesów diagenetycznych, jak rozpuszczanie i przeobrażanie. 

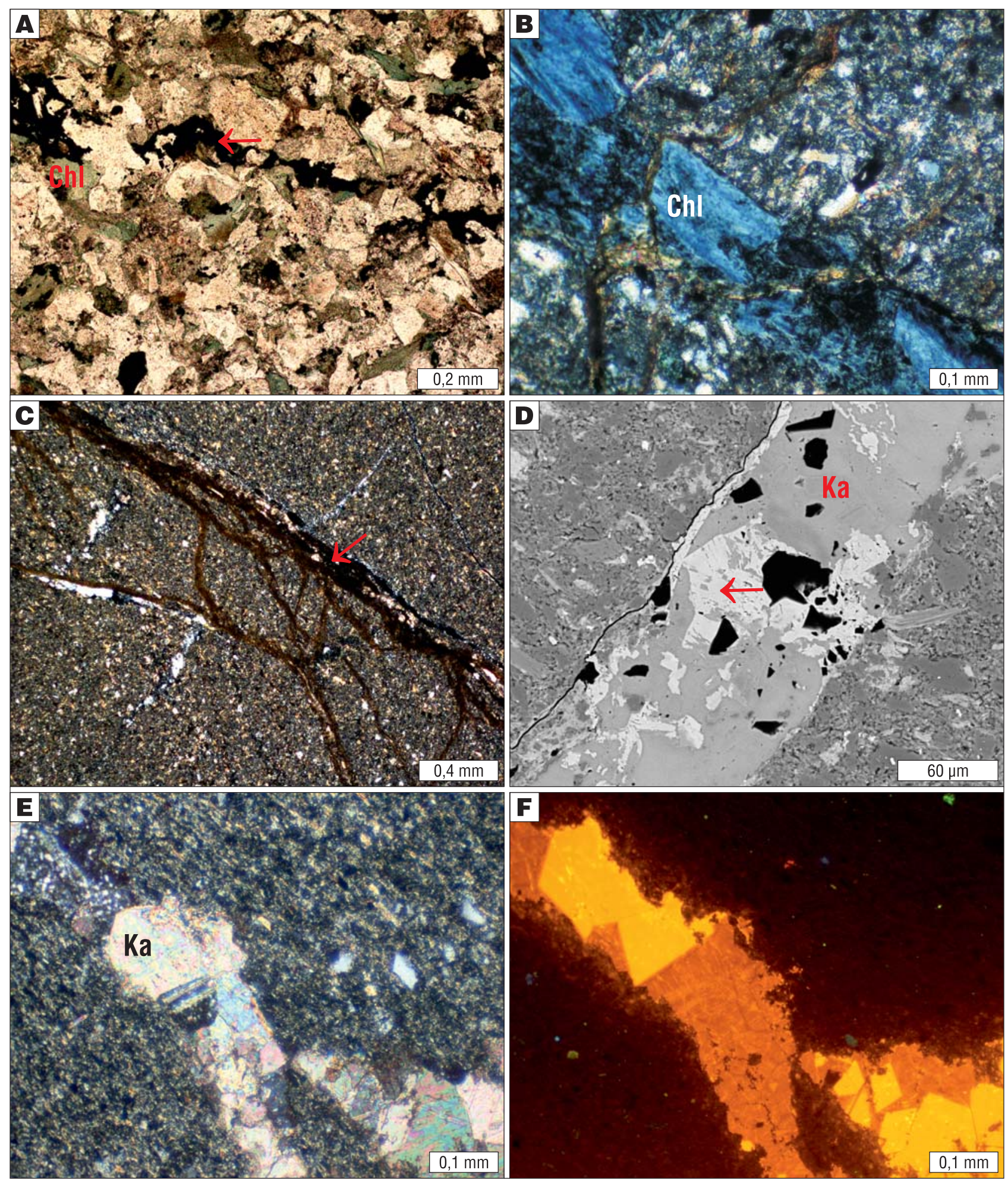

Ryc. 2. Mikrolitofacje badanych skał obserwowane pod mikroskopem polaryzacyjnym (PL), w katodoluminescencji (CL) i skaningowym mikroskopie elektronowym (BSE): A - piaskowiec drobnoziarnisty o składzie waki sublitycznej/subarkozowej, widoczne chloryty (Chl) i bituminy (strzałka), głęb. 793,6 m, obraz PL, bez analizatora; B - skupienia chlorytów (Chl) w bardzo drobnoziarnistym piaskowcu, głęb. 881,1 m, PL, nikole skrzyżowane; C - iłowiec z siecią żyłek syderytowych (strzałka), głęb. 1129,6 m, PL, nikole skrzyżowane; D - żyłka węglanowa w iłowcu wypełniona kalcytem (Ka) i Mn-syderytem (manganosyderyt, strzałka), głęb. 1258,7 m, obraz BSE; E - żyłka kalcytowa (Ka) w iłowcu, głęb. 1045,8 m, PL, nikole skrzyżowane; F - obraz CL próbki z ryc. E - dwie generacje kalcytu: starsza o żółtej barwie luminescencji i młodsza o barwie pomarańczowej

Fig. 2. Microlithofacies in polarizing microscope (PL), cathodoluminescence (CL) and scanning electron microscope (BSE): A - fine-grained sandstone with the composition of sublithic/subarkosic, chlorites (Chl) and bitumens (arrowed) are visible, depth $793.6 \mathrm{~m}$, $\mathrm{PL}$ - one polarizer; $\mathbf{B}$ - accumulation of chlorites $(\mathrm{Chl})$ in very fine-grained sandstone, depth $881.1 \mathrm{~m}, \mathrm{PL}$, crossed polarizers; $\mathbf{C}$ - claystone with a net of siderite veins (arrowed), depth $1129.6 \mathrm{~m}, \mathrm{PL}$ - crossed polarizers; D - carbonate vein in siltstone filled with calcite (Ka) and Mn-siderite (manganosiderite, arrowed), depth $1258.7 \mathrm{~m}$, BSE image; $\mathbf{E}$ - calcite (Ka) vein in claystone, depth $1045.8 \mathrm{~m}, \mathrm{PL}$ - crossed polarizers; $\mathbf{F}$ - sample shown in Figure E, CL image - two generations of calcite: older - yellow luminescence and younger orange luminescence 


\section{$\rightarrow$}

Ryc. 3. Diagram trójkątny składu chemicznego minerałów węglanowych [\% mol.]; nliczba analiz

Fig. 3. Triangle diagram of the chemical composition [mol\%] of carbonates; $\mathbf{n}$ - number of analyses

Litofacje mułowcowa, pyłowcowa i iłowcowa w profilu otworu Bibiela PIG-1 (ryc. 2C-F) często się zazębiają, przeławicają i współwystępują. Iłowce i pyłowce są podstawowymi rodzajami skał w analizowanym profilu ediakaru, mułowce zaś występują głównie jako cienkie przewarstwienia $\mathrm{w}$ ich obrębie. Skały te są barwy zielonkawooliwkowej lub beżowej, rzadko brunatnej, na skutek większego nagromadzenia związków żelaza. Wykazują strukturę pelitową, pelitowo-aleurytową lub aleurytową. Teksturę mają bezładną, miejscami kie-

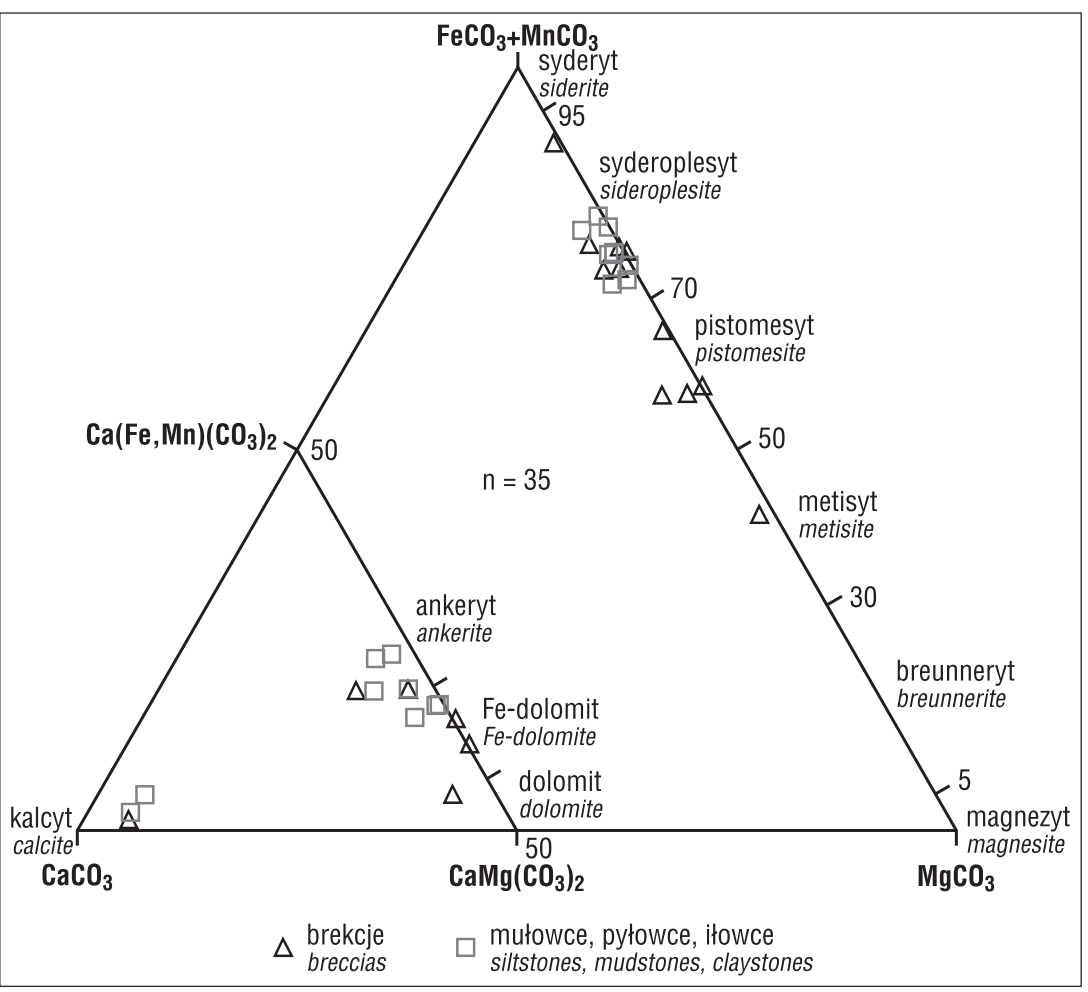
runkową, podkreśloną laminami o nieco innym składzie mineralnym lub ułożeniem minerałów ilastych. Frakcja aleurytowa jest złożona przede wszystkim z ziaren nieobtoczonego lub półobtoczonego kwarcu. Powszechne są ziarna skaleni potasowych, często obserwowano apatyt, natomiast plagioklazy, fragmenty skał, łyszczyki, monacyt, cyrkon i piryt występują w mniejszej ilości. Zauważono również skupienia bituminów. Miejscami w masie ilastej zidentyfikowano owalne formy określone jako fosfoklasty. W toku analizy dyfraktometrycznej skał mułowcowo-iłowcowych niemal we wszystkich badanych próbkach potwierdzono obecność: kwarcu, skaleni (sodowych, sodowo-wapniowych i potasowych), illitu, chlorytu oraz węglanów. Sporadycznie odnotowano występowanie kaolinitu, muskowitu, hematytu i gipsu. Wśród węglanów najczęstszy jest kalcyt, natomiast sporadycznie pojawiają się dolomit, ankeryt, syderyt i magnezyt. Wśród minerałów ilastych $\mathrm{z}$ frakcji $<0,2 \mu \mathrm{m}$ zidentyfikowano głównie illit, któremu towarzyszą chloryty, kaolinit i minerały mieszanopakietowe illit/smektyt. W badanych skałach chloryty występują także w formie żyłek i nieregularnych skupień grubokrystalicznych. Bardzo często minerałom ilastym towarzyszą tlenki i wodorotlenki żelaza. Podobnie jak piaskowce i brekcje, skały iłowcowo-pylaste są poprzecinane licznymi żyłkami. Są one wypełnione węglanami, wśród których zidentyfikowano Mn/Fe-kalcyt, Fe-dolomit, ankeryt, Mg-syderyt (syderoplesyt) i Mn-syderyt (manganosyderyt; ryc. 2C-F, 3). Cienkie żyłki syderoplesytu układają się w skomplikowane, splątane formy nitkowate (ryc. 2C). Pozostałe węglany mogą tworzyć również większe skupienia gniazdowe. Lokalnie w gnieździe wypełnionym ankerytem zidentyfikowano baryt. Ponadto jako wypełnienie żyłek występują: kaolinit, kwarc i chloryty. Miejscami w żyłkach obserwowano drobne kryształy galeny i sfalerytu.

\section{Charakterystyka minerałów ilastych}

W badanych skałach głównym minerałem ilastym jest illit, któremu towarzyszą chloryty, kaolinit i minerały mieszanopakietowe illit/smektyt. Zawartość illitu w strukturach illit/smektyt zmienia się od 75 do $80 \%$ w brekcjach i od 80 do $90 \%$ w iłowcach, mułowcach oraz pyłowcach. Zbadano także tzw. stopień krystaliczności illitu, określany jako indeks Küblera (KI), który jest stosowany do określania stopnia diagenezy. Indeks KI wybranych próbek brekcji, z zakresu głęb. 718,3-881,1 m wyniósł od 0,72 do $0,88 \Delta^{\circ} 2 \theta$ $\mathrm{CuK}_{2}$, natomiast indeks piaskowców oraz iłowców, mułowców i pyłowców, z zakresu głęb. 834,8-1573,5 m - od 1,00 do $1,10 \Delta^{\circ} 2 \theta \mathrm{CuK}_{2}$. Szczegółowym badaniom poddano chloryty zawarte we frakcji ilastej w trzech próbkach. Zidentyfikowano struktury $1 \mathrm{M}$ typu IIb w postaci trioktaedrycznych chlorytów magnezowych i magnezowo-żelazistych (klinochlor Fe).

\section{Charakterystyka materii organicznej}

Zawartość materiału organicznego w piaskowcach ediakaru waha się od ilości śladowych do 1,2\% planimetrowanej powierzchni próbki. Skały te charakteryzują się śladową zawartością witrynitopodobnej materii organicznej, reprezentowanej przez stałe bituminy oraz fytoklasty (również rozproszony detrytus organiczny). Zdolność refleksyjna, zmierzona na materiale witrynitopodobnym, zmienia się w obrębie pojedynczej próbki najczęściej w granicach $1,45-1,91 \% \mathrm{R}_{\mathrm{o}}$, a jej średnia wartość waha się od 1,68 do $1,87 \% \mathrm{R}_{\mathrm{o}}$. Za najbardziej miarodajną oraz reprezentatywną uznano próbkę z głębokości 881,1 m, dla której uzyskano Ro $=1,68 \%$. W trzech próbkach skrajne wartości współczynnika refleksyjności wahają się w granicach $1,47-2,83 \% \mathrm{R}_{\mathrm{o}}$, a ich wartości średnie wynoszą 2,06-2,24\% $\mathrm{R}_{0}$. 


\section{Warunki paleotemperaturowe}

Skały ediakaru są silnie zdiagenezowane, a także zdeformowane oraz spękane. Spękania są wypełnione bogatą mineralizacją węglanową (kalcyt, dolomit, ankeryt, syderyt), kwarcową, kaolinitowa, chlorytową i kruszcowa, a niekiedy są w nich obecne bituminy. Stwierdzony zespół minerałów jest typowy dla warunków diagenetycznych lub hydrotermalnych, niskotemperaturowych.

W celu określenia maksymalnej paleotemperatury, jaka oddziaływała na badane skały, wykonano badania dojrzałości termicznej materii organicznej. Wartość $\mathrm{R}_{\mathrm{o}}=1,68 \%$ wskazuje na stopień dojrzałości odpowiadający głównej fazie generowania gazu, co sugeruje paleotemperatury rzędu $140^{\circ} \mathrm{C}$. Wyższe średnie wartości oznaczeń współczynnika refleksyjności danej próbki, sięgające 2,24\% $\mathrm{R}_{\mathrm{o}}$, mogą być efektem lokalnego podgrzania osadu do ok. $160^{\circ} \mathrm{C}$. Dodatkowych przesłanek do oszacowania warunków paleotemperaturowych dostarczają badania frakcji ilastej. Pomiar wskaźnika Küblera w illicie, w próbkach skał z zakresu głębokości od 718,3 do 1573,5 m, waha się w granicach od 0,72 do $1,10 \Delta^{\circ} 2 \theta \mathrm{CuK}_{2}$. Analizowano także zawartość smektytu w minerałach mieszanopakietowych illit/smektyt, która świadczy o zaawansowaniu procesu transformacji smektytu w illit. W badanych próbkach udział smektytu w strukturach illit/smektyt waha się od 10 do $25 \%$ (średnia wartość $16 \%$ ), co szacunkowo odpowiadałoby paleotemperaturze rzędu $140-150^{\circ} \mathrm{C}$ (Środoń, 1996).

Granicę pomiędzy późną diagenezą a dolną anchizoną, odpowiadającą temperaturze $200^{\circ} \mathrm{C}$ (Frey, Robinson, 1999), wyznaczają m.in. wartość wskaźnika Küblera $=0,42 \Delta^{\circ} 2 \theta$ i procentowa zawartość illitu w minerałach mieszanopakietowych illit/smektyt $=90 \%$.

Uzyskane wyniki badań wskazują na przemiany diagenetyczne w badanych skałach bez znamion warunków anchimetamorficznych. Reasumując, badane skały ediakaru w otworze wiertniczym Bibiela PIG-1 zostały przeobrażone w warunkach późnej diagenezy, w maksymalnej temperaturze szacowanej na ok. $160^{\circ} \mathrm{C}$.

\section{WNIOSKI}

1) W profilu Bibiela PIG-1 wyróżniono litofacje: brekcjowa, piaskowcowa, mułowcową, pyłowcową i iłowcową. Podstawowymi rodzajami skał są iłowce i pyłowce z cienkimi przewarstwieniami mułowców. Powszechnie występują brekcje, natomiast piaskowce stanowią pakiety niewielkiej miąższości lub cienkie przeławicenia w iłowcach lub pyłowcach.

2) W iłowcach, pyłowcach i mułowcach do frakcji ilastej należą: illit, minerały mieszanopakietowe illit/smektyt oraz chloryty. Bardzo często towarzyszy im rozproszona materia organiczna lub wodorotlenki żelaza. W brekcjach w składzie frakcji psefitowej wyróżniono okruchy iłowców, mułowców i pyłowców. Wśród ziaren frakcji pelitowej i aleurytowej wyróżniono: kwarc, skalenie łysz- czyki, glaukonit, fosforany i minerały nieprzezroczyste, które są spojone substancją ilastą, miejscami ilasto-żelazistą. Piaskowce o strukturze psamitowej lub psamitowo-aleurytowej składem odpowiadają wakom sublitycznym lub też subarkozowym.

3) Skały ediakaru mają liczne, wzajemnie przecinające się żyłki. Żyłki te są wypełnione węglanami, kwarcem, chlorytami, a także kaolinitem. Wśród minerałów węglanowych zidentyfikowano: ankeryt, Fe-dolomit, dolomit, Mg-syderyt (syderoplesyt, pistomesyt i metisyt), Mn-syderyt (manganosyderyt) oraz Fe/Mn-kalcyt.

4) Wskaźnik refleksyjności witrynitu $-\mathrm{R}_{\mathrm{o}}=1,68 \%$, wskaźnik Küblera - KI w granicach od 0,72 do $1,10 \Delta^{\circ} 2 \theta$ $\mathrm{CuK}_{2}$ oraz zawartość 10-25\% smektytu w minerałach mieszanopakietowych illit/smektyt wskazują, że skały ediakaru w otworze wiertniczym Bibiela PIG-1 zostały przeobrażone w warunkach późnej diagenezy, w maksymalnej temperaturze szacowanej na ok. $160^{\circ} \mathrm{C}$.

Autorki dziękują Recenzentom: dr hab. K. Jarmołowicz-Szulc i prof. dr. hab. inż. Z. Sawłowiczowi za cenne uwagi i komentarze, które wpłynęły na ostateczną wersję artykułu. W publikacji przedstawiono wyniki badań sfinansowanych przez NFOŚiGW, realizowanych w ramach Programu wierceń badawczych państwowej stużby geologicznej PIG-PIB - Wiertnicze zbadanie nierozpoznanych profili prekambru i dolnego paleozoiku w pótnocno-wschodniej części bloku górnoślaskiego i ich potencjatu złożowego. Etap I-otwór badawczy Bibiela PIG-1. Artykuł został opracowany w ramach zadania Wspótpraca krajowa $w$ zakresie geologii i promocja działań państwowej służby geologicznej w latach 2021-2023 i sfinansowany ze środków NFOŚiGW.

\section{LITERATURA}

BUŁA Z., HABRYN R. (red.) 2008 - Atlas geologiczno-strukturalny paleozoicznego podłoża Karpat zewnętrznych i zapadliska przedkarpackiego w skali 1:300 000. Państw. Inst. Geol.

FREY M., ROBINSON D. 1999 - Low grade metamorphism. Blackwell Science, Oxford.

HABRYN R. (red.) 2017 - Dokumentacja geologiczna otworu badawczego Bibiela PIG-1 dla potrzeb przedsięwzięcia z dziedziny geologii pod tytułem „Program wierceń badawczych państwowej służby geologicznej PIG-PIB - Wiertnicze zbadanie nierozpoznanych profili prekambru i dolnego paleozoiku w północno-wschodniej części bloku górnośląskiego i ich potencjału złożowego. Etap I - otwór badawczy Bibiela PIG-1". Nar. Arch. Geol. Państw. Inst. Geol., Warszawa, nr $5689 / 2020$

HABRYN R., BAGIŃSKA A. 2020 - Otwór Bibiela PIG 1 - nowe spojrzenie na budowę geologiczną północnej części bloku górnośląskiego. Newsleter PIG-PIB, 13.

MOORE D.M., REYNOLDS R.C.Jr. 1989 - X-Ray diffraction and identification and analysis of clay minerals. Oxford University Press, Oxford. PETTIJOHN F.J., POTTER P.E., SIEVER R. 1972 - Sand and sandstone. Springer-Verlag, New York.

MARKOWIAK M., HABRYN R. 2020 - Przejawy mineralizacji polimetalicznej w strukturze elewacji Brudzowic (Siewierza) na bloku górnośląskim (południowa Polska). Prz. Geol., 68 (6): 511-525.

PACZEŚNA J. 2014 - Litostratygrafia utworów ediakaru w lubelsko-podlaskim basenie sedymentacyjnym (wschodnia i południowo-wschodnia Polska). Biul. Państw. Inst. Geol., 460: 1-24.

ŚRODOŃ J. 1996 - Minerały ilaste w procesach diagenezy. Prz. Geol., 44 (6): 604-607.

TUCKER M.E. 2001 - Sedimentary petrology. Blackwell Publishing.

Praca wpłynęła do redakcji 8.04.2021 r.

Akceptowano do druku 4.05.2021 r. 


\section{Charakterystyka mikrolitofacji oraz warunków paleotemperaturowych skał ediakaru w otworze wiertniczym Bibiela PIG-1 (patrz str. 374)}

The characteristics of microlithofacies and palaeotemperature conditions of Ediacaran rocks in the Bibiela PIG-1 borehole (see p. 374)
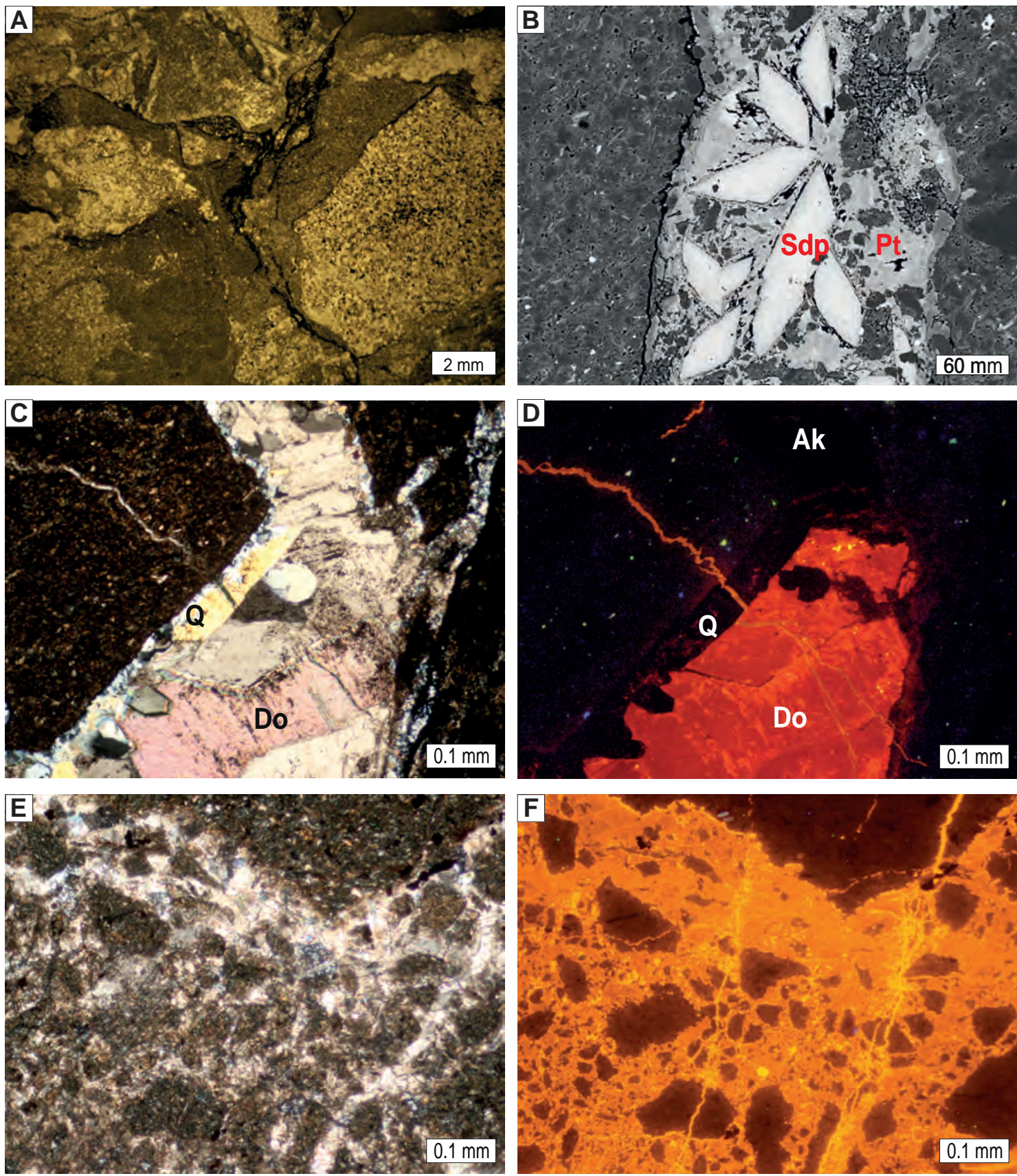

Ryc. 1. Mikrolitofacje skał ediakaru z profilu otworu Bibiela PIG-1 - obserwowane pod mikroskopem polaryzacyjnym (PL), w katodoluminescencji (CL) i skaningowym mikroskopie elektronowym (BSE): A - fragment brekcji składającej się z okruchów mułowców i iłowców, głęb. 994,9 m, obraz PL, bez analizatora; B - żyłka węglanowa w brekcji wypełniona romboedrami syderoplesytu (Sdp) i pistomesytem (Pt), głęb. 730,3 m, obraz BSE; C - żyłka wypełniona dolomitem (Do), ankerytem (Ak) i kwarcem (Q) w brekcji, głęb. 714,6 m, PL, nikole skrzyżowane; D - obraz CL próbki z ryc. C - dolomit (Do) wykazuje luminescencję w barwie czerwonej, ankeryt (Ak) i kwarc (Q) nie świecą; E - żyłki kalcytowe (Ka) w brekcji, głęb. 1099,3 m, PL, nikole skrzyżowane; $\mathbf{F}$ - obraz CL próbki z ryc. E, dwie generacje żyłek kalcytowych: starsza o żółtej barwie luminescencji i późniejsza o barwie pomarańczowej

Fig. 1. Ediacaran microlithofacies in the Bibiela PIG-1 borehole in polarizing microscope (PL), cathodoluminescence (CL) and scanning electron microscope (BSE): A - fragment of breccia composed of mudstone and claystone clasts, depth 994.9 $\mathrm{m}, \mathrm{PL}$ - one polarizer; $\mathbf{B}$ - carbonate vein in breccia filled with sideroplesite (Sdp) rhombohedrons and pistomesite $(\mathrm{Pt})$, depth $730.3 \mathrm{~m}$, BSE image; C - vein filled with dolomite (Do), ankerite (Ak) and quartz (Q) in breccia, depth 714.6 m, PL, crossed polarizes; D - sample shown in Figure C, CL image - dolomite (Do) red luminescence, ankerite (Ak) and quartz (Q) - non-luminescence; E - calcite (Ka) veins in breccia, depth 1099.3 m, PL, crossed polarizes; F - sample shown in Figure E, CL image, two generations of calcite veins: older - yellow luminescence and younger - orange luminescence 